\title{
Behavior of circulating epithelial tumor cells (CETC) and FISH (fluorescence in situ hybridisation) of epidermal growth factor receptor (EGFR)-gene amplification in lung cancer patients during the course of therapy
}

\author{
May EI Sherif ${ }^{1,2}$, Claus Peter Schneider ${ }^{2}$, Carola Rabenstein ${ }^{3}$, Amina Hessein Hassab $^{4}$, \\ Magdy Mamdouh El Bordiny ${ }^{4}$, Mona Wagdy Ayad ${ }^{4}$, Katharina Pachmann ${ }^{1^{*}}$

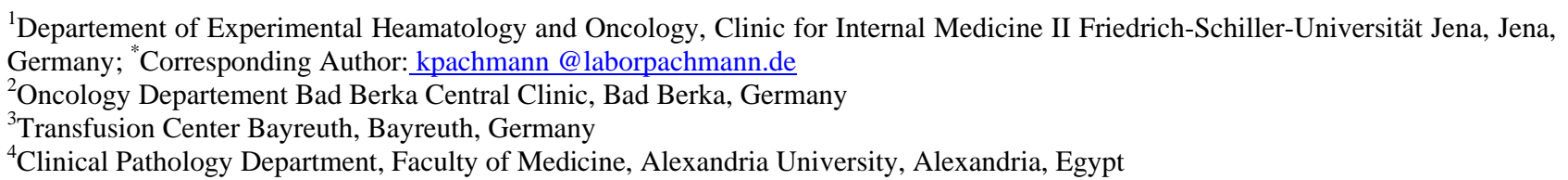

Received 4 January 2013; revised 18 February 2013; accepted 28 February 2013

\section{ABSTRACT}

Introduction: Monitoring the response of CETC to therapy in lung cancer allows early detection of patients at risk of progression. Analysis of the EGFR-gene amplification in these cells may help to characterize patients who might benefit from tyrosine kinase inhibitors. Methods: CETCs were quantified at least twice during treatment from blood of 52 patients with advanced non small cell lung cancer (NSCLC) using fluorescence labelled anti-EpCAM. EGFR-gene amplification was analysed in these cells with double probe (EGFR/CEP7) using FISH analysis. Results: Progression of the tumor was observed in $\mathbf{3 0}$ of the 52 patients $(58 \%)$. With respect to changes in CETCs during therapy and progression free survival 31 patients showed a decrease in CETCs, 2 developing a single brain metastasis and 12 progressive disease; 20 patients showed an increase in CETC more than twofold 16 of which developed progressive disease. The difference was highly significant ( $p=0.007$ Fisher's exact test) irrespective of age, sex, tumor size, pathological type and therapy. Kaplan-Meier progression free survival was significantly different between patients with decreasing and increaseing CETC $(p=0.038)$. 5/20 patients tested were positive for EGFR amplification with $85 \%-100 \%$ of EpCAM positive cells showing this chromosomal abnormality. One patient could be followed during therapy with increasing CETC during therapy with bevacizumab followed by relapse. He subsequently received erlotinib resulting in a decrease in CETC and is still free of progress after $\mathbf{5 1 6}$ days. Conclusions: These results show that peripherally circulating tumor cells in patients with advanced NSCLC are influenced by systemic chemotherapy and an increase in spite of therapy is a marker of aggressiveness of the tumor cells. Determination of the EGFR amplification might help to better treat part of these patients.

Keywords: Circulating Epithelial Tumor Cells; Lung Cancer; EGFR-Gene Mutation; Amplification; FISH

\section{INTRODUCTION}

Lung cancer is the leading cause of cancer death worldwide with 1.1 million deaths annually [1].

5 years lung cancer survival rate has remained at $13 \%$ - 15\% throughout the past 3 decades despite innovations in diagnostic testing, surgical techniques and development of new chemotherapeutic agents [2].

Recent data have demonstrated that tumors contain a small subpopulation of cancer stem like cells (CSCs) or cancer initiating cells (CICs) which exhibit a self renewing capacity and are responsible for tumor maintenance and metastasis formation [3]. It is possible that the poor outcome of lung cancer is attributable to fundamental differences in tumor biology as compared to other tumors (e.g. breast cancer) or to special properties of can- 
cer stem cells from which lung carcinomas arise which is capable of differentiation into one or several histological cell types [4].

Solid tumors can also seed tumor cells into peripheral blood. The detection of circulating tumor cells in peripheral blood was first suggested more than a century ago [5] but has only recently become a clinical reality. It is now clear that cells are shed from tumors well before metastasis formation [6]. They can be shed from the tumor at all stages of disease and may remain in the patient's circulation for lengthy periods $[7,8]$. A small fraction of these cells, probably the tumor stem cells, can develop into metastases even after complete resection of the tumor.

Detection of such circulating tumor cells has been reported in the blood $[9,10]$ and bone marrow $[11,12,13]$ of patients with primary breast cancer and in patients with lung cancer [14]. Even therapeutic manipulation such as surgery can contribute to the seeding of epithelial cells $[14,15]$. These cells may, however, differ in their proliferative and metastatic potential $[16,17]$.

Therefore, monitoring the behavior (increase or decrease) rather than merely detection of circulating tumor cells could provide a novel approach for timely detection of imminent recurrence and evaluation of treatment response for many cancers.

Several methods have been proposed for the detection and enumeration of circulating tumor cells including negative selection by flow cytometry, nucleic acid based approaches and selective isolation followed by immunofluorescence microscopy $[18,19,20]$.

In the present study we have added a novel nondissipative approach for the characterization of CETCs based on a combination of antibody fluorescence detection using fluorescence scanning microscopy together with fluorescence in situ hybridization for EGFR-gene amplification in these CETCs.

EGFR is a tyrosine kinase receptor and has been implicated in the proliferation and survival of cancer cells. Mutations and aberrant expression of EGFR has been detected in many human epithelial malignancies including NSCLC and this receptor has been identified as a promising target for anticancer therapy. Several agents have been synthesized to inhibit its tyrosine kinase activity [21,22].

Amplified EGFR copy number has been associated with increased sensitivity to these drugs, however, given that it is often difficult to obtain sufficient amount of primary tumor tissue for genetic analysis from patients with advanced NSCLC, the relationship between EGFR mutation and gene amplification has remained unclear [23].

In addition to studying the response of the CETCs to the applied therapy we evaluated EGFR-gene amplifica- tion in circulating tumor cells from selected patients with advanced NSCLC by FISH technique. We show that a decline of CETC numbers in response to the applied therapies in lung cancer correlates with better progression free survival and first data indicate that also a response of CETCs of a patient with the EGFR amplification to treatment can be monitored and correlates with disease response.

\section{METHODS}

From September 2009, 52 patients with pretreated progressive NSCLC consented to blood drawing according to the ethics committee approval.

Applied chemotherapies were: carboplatin or cisplatin with docetaxel or vinorelbin, with or without bevacizumab, carboplatin with ixabepilone, pemetrexed with bevacizumab and carboplatin together with or without TKI (Tyrosine kinase inhibitors). Blood which had been anticoagulated with EDTA was drawn before and after chemotherapy and/or during follow up. $1 \mathrm{ml}$ was lysed with ammonium chloride (Qiagen Hilden, Germany) and analysed using the previously described microfluorimetric method, where assay method, stability of the sample and reproducibility have been extensively described [9].

In short, in order to compensate for shipping delays, samples were subjected to red blood cell lysis at day 2 after blood drawing (with usually 95\% viability) using $10 \mathrm{ml}$ of erythrocyte lysis solution (Qiagen Hilden, Germany) for 10 minutes at room temperature, spun down at $700 \mathrm{~g}$ and rediluted in $1 \mathrm{ml}$ of PBS (Phosphate buffer saline) $\mathrm{pH}$ 7.4.10 $\mu \mathrm{l}$ of fluorescein isothiocyanate (FITC)conjugated mouse antihuman epithelial antibody (HEA) (Milteny Bergish, Gladbach Germany) was added to 100 $\mu \mathrm{l}$ of cell suspension incubated for 15 min in the dark, readjusted to $1 \mathrm{ml}$ and a defined volume of the cell suspension was applied to a defined area into wells of an ELISA plate. The adherent cells were measured using image analysis in a Scan-R microscope (Olympus, Munich, Germany). Values were displayed in scattergrams and histograms. Both approaches enable the user to locate cells contained within the desired population for visual examination and to take fluoromicrographs [24].

For FISH analysis slides with positively immuno-labelled cells were incubated for 10 minutes in paraformaldehyde (2 g paraformaldehyde in $500 \mathrm{ml}$ PBS) for 5 minutes at room temperature, then $50 \mu \mathrm{l}$ proteinase $\mathrm{K}$ were added. The slides were incubated in post hybridisation washing buffer (20× SSC, NP-40 with $\mathrm{NaOH}$ of $\mathrm{pH}$ 7 - 7.5) at room temperature and left to dry followed by 5 minutes in fresh formamide followed by dehydration in ethanol series (75\%, 85\% and 100\% 30 seconds each).

$10 \mu \mathrm{l}$ of EGFR enumeration probe (red) with chromosome 7 enumeration probe (CEP) (green) were added to the slides and mixed with hybridisation buffer covered 


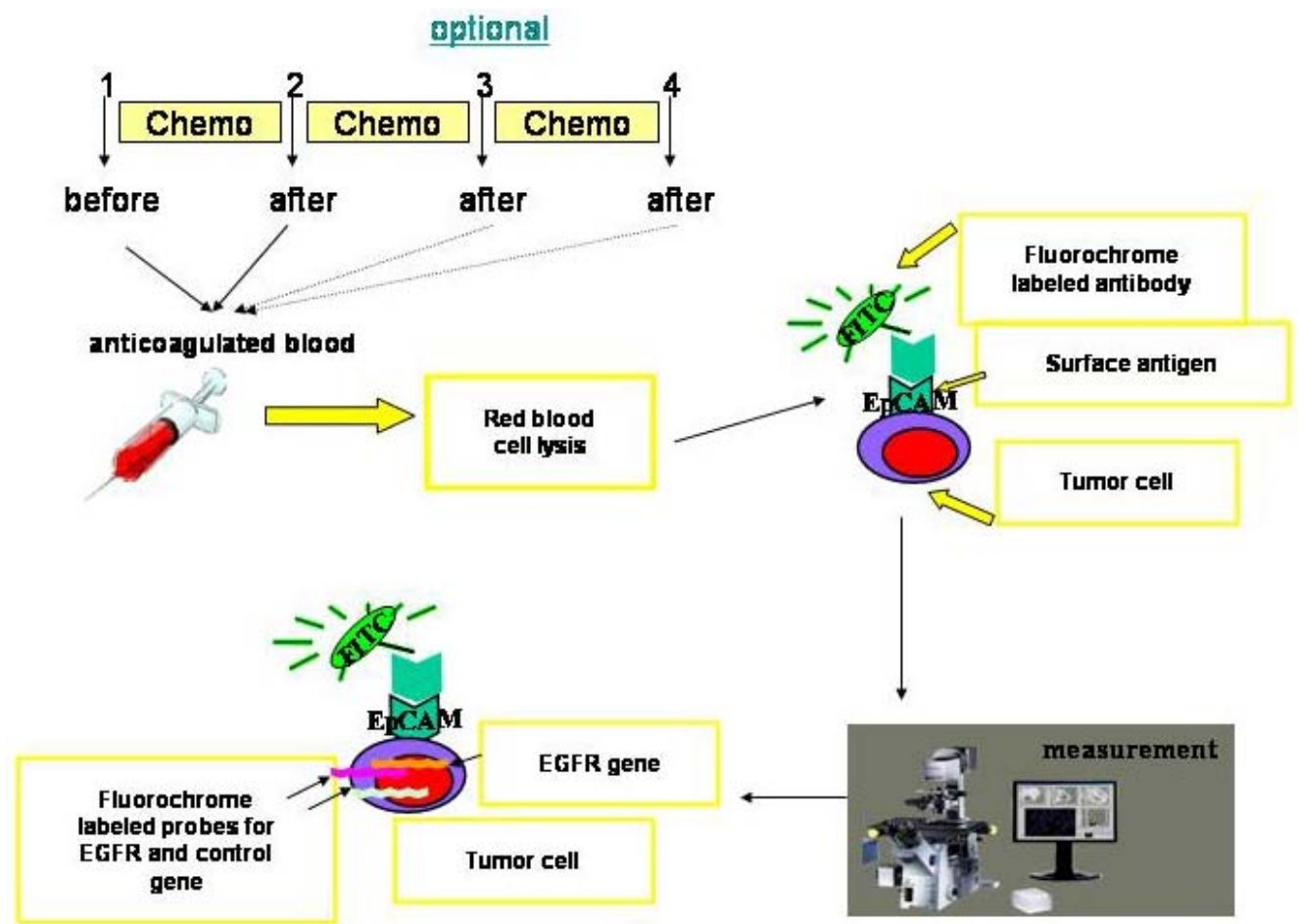

Figure 1. Flow chart of the approach for tumor cell staining and detection.

(a)

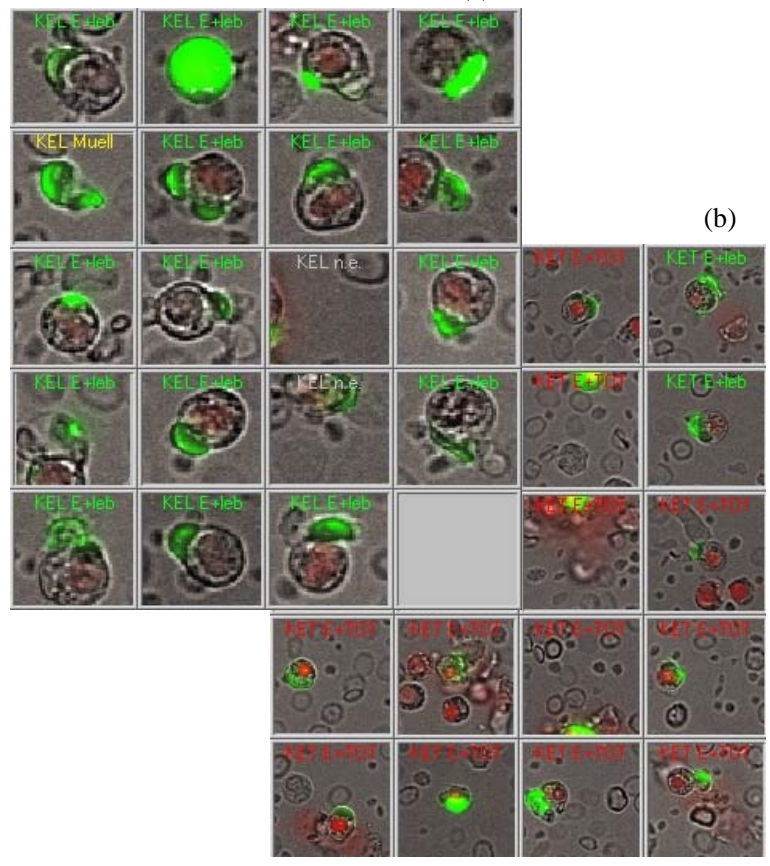

Figure 2. Example of the visual verification of viable circulating epithelial tumor cells among the gallery of positive events provided by the automated image analysis program looking for exclusive surface EpCAM staining. (a) shows a gallery of live CETC (b) shows dead CETC.

with a cover slip, sealed and denaturated. Hybridisation was performed according to manufacturer's instructions (Vysis, Downers Grove, IL, USA).
Following overnight hybridisation the slides were washed in pre-warmed $72^{\circ} \mathrm{C}$ posthybridisation buffer (0.3\% NP 40, 20× SSC) for 2 minutes, after air drying for 2 minutes the specimens were cover slipped with DAPI-containing vectashield mounting medium. Identification and quantification of FISH signals were performed using Carl-Zeiss fluorescence microscope. Cells were first scanned at low magnification $(\times 10)$ to identify cells carrying immuno-labelling. Positive cells were then revisited at high magnification $(\times 100)$ for verification and enumeration of FISH signals [21]. The procedure is depicted in the flow chart (Figure 1). Statistical analysis for the confounding variables including tumor size at time of the diagnosis, age, sex, pathological type and different tumor markers were performed using the SPSS program (Version 16).

\section{RESULTS}

The characteristics and the distribution of tumors with respect to age, tumor size at time of diagnosis, pathological size, relapse, and EGFR-gene amplification of all patients are shown in Table $\mathbf{1}$.

All lung cancer patients could be analysed for vital epithelial cells before the onset of the respective therapy. Figure 2 shows a gallery of vital and dead cells from a typical analysis from one patient. In a previous study no live epithelial antigen positive cells were detected in $97 \%$ of healthy donors aged between 17 and 75 years [9].

51 patients could subsequently be analyzed for their 
Table 1. Characterization of the 52 patients.

\begin{tabular}{|c|c|c|}
\hline & No & Percent \\
\hline $\begin{array}{l}\text { Age } \\
\text { Range } \\
\text { Mean } \\
\text { S.D. }\end{array}$ & $\begin{array}{c}37-85 \\
66.54 \\
10.340\end{array}$ & \\
\hline \multicolumn{3}{|l|}{ Tumor type } \\
\hline Adeno & 19 & 36 \\
\hline Alveolar & 1 & 2 \\
\hline Large cell & 3 & 6 \\
\hline Squamous cell & 28 & 54 \\
\hline Pleomorphic & 1 & 2 \\
\hline \multicolumn{3}{|l|}{ Tumor size } \\
\hline T1-2 & 30 & 58 \\
\hline T3-4 & 22 & 42 \\
\hline \multicolumn{3}{|l|}{ Fish(EGFR-gene amplification) } \\
\hline Negative & 15 & 29 \\
\hline Positive & 5 & 10 \\
\hline Not analysed & 32 & 61 \\
\hline \multicolumn{3}{|l|}{ Sex } \\
\hline Male & 33 & 63 \\
\hline Female & 19 & 37 \\
\hline \multicolumn{3}{|l|}{ Change in CETC } \\
\hline Decrease & 31 & 60 \\
\hline Marked increase $>$ twofold & 20 & 38 \\
\hline Not analysed & 1 & 2 \\
\hline \multicolumn{3}{|l|}{ Progressive disease } \\
\hline No & 20 & 40 \\
\hline Yes & 28 & 60 \\
\hline Brain only & 2 & \\
\hline Not available & 2 & \\
\hline
\end{tabular}

CETC after chemotherapy. This allowed to monitor the response of CETCs to therapy for each of these patients. CETC numbers decreased in 31 patients (60\%) and increased more than twofold in 20 patients (38\%) (Figures 3(a) and (b)).

Therapy response of the CETC was correlated to course of disease during the observation time. Progression occurred in 30 of the 52 patients (58\%), 2 developing a single brain metastasis. Since none of the drugs, used in this study can trespass the blood/brain barrier, such metastases can develop even if the drugs are pe ripherally active. Therefore these patients were excluded

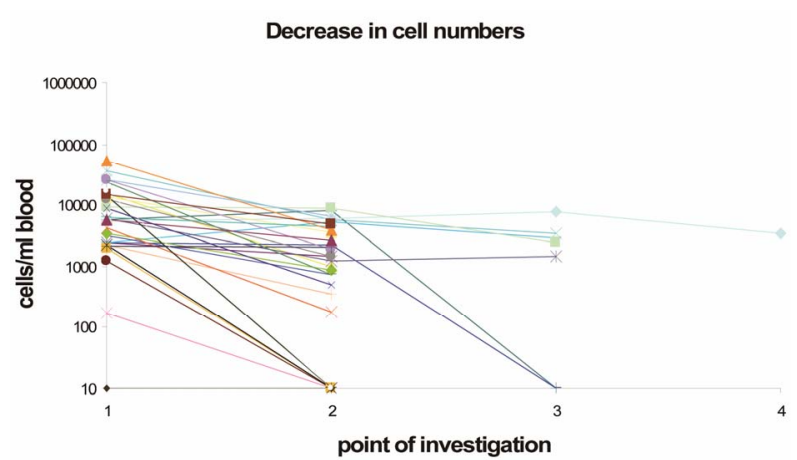

(a)

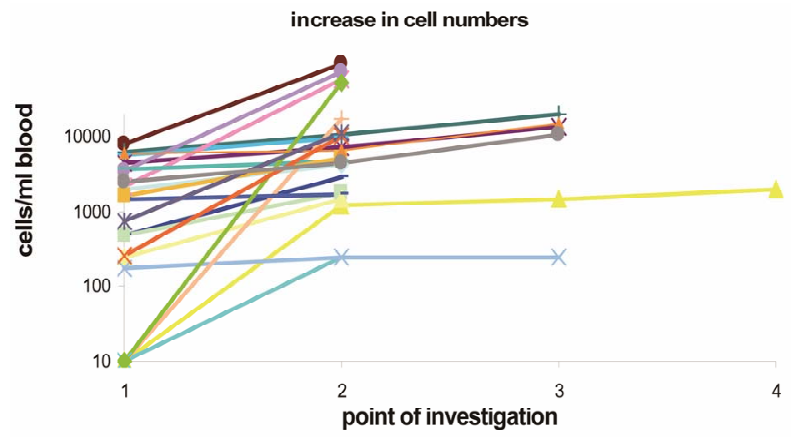

(b)

Figure 3. Changes in cell numbers during therapy in 51 patients (a) with CETC numbers decreasing more than two-fold during therapy and (b) increase in CETC numbers more than twofold during therapy.

from the subsequent analysis. In 2 patients no data about outcome were available.

Disease progression was observed in 12/28 remnant patients with decreasing numbers of CETC during therapy (41\%) and in 16/20 patients with increasing CETC $(80 \%)$ and this difference was highly significant $(\mathrm{p}=$ 0.007).

The Kaplan-Meier analysis showed a highly significant difference in progression free survival between the group with increasing CETC numbers and the group with decreasing CETC numbers (Figure 4) with $\mathrm{p}=0.038$ and a hazard ratio of 1.99).

Concerning FISH results, 5 of the 20 analyzed cases were positive EGFR/CEP > 2, where more than $85 \%$ of EpCAM positive cells showed this chromosomal abnormality. Figure 5 shows typical pictures of 1) 4 normal blood cells with two signals and 2) a tumor cell of the same patient with more than 10 amplificates. There was no significant relationship between FISH results (EGFRgene amplification frequency) and sex, age or change in circulating tumor cells in response to the conventional therapies.

One of the patients shown in Figure 6 showed an increase in CETC under therapy with bevacizumab with progress but subsequently was treated with the tyrosine kinase inhibitor erlotinib with a decrease in CETCs and 


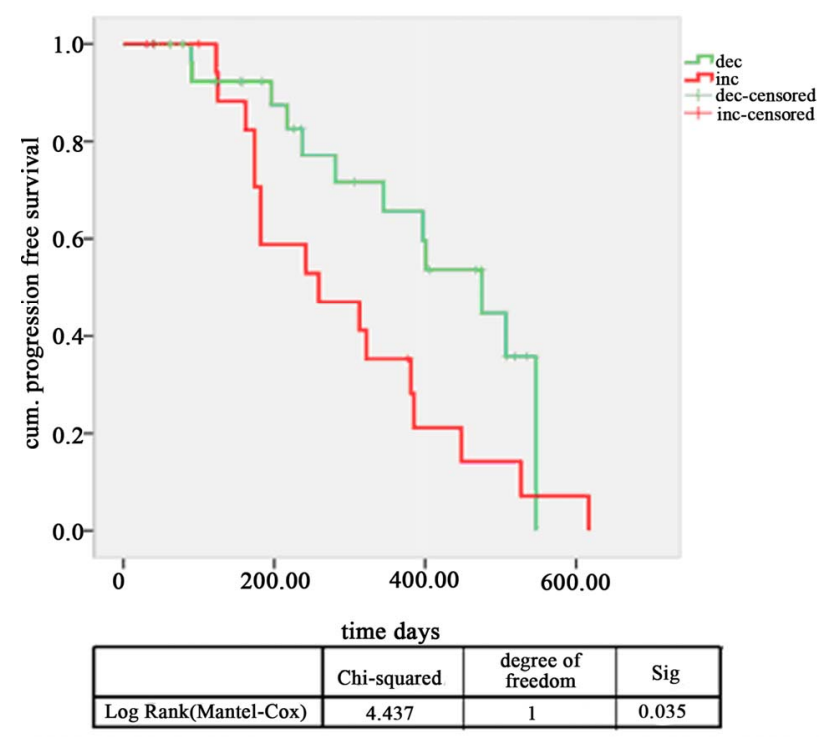

Figure 4. Kaplan-Meier progression free survival curves of patients with decreasing CETC (green line) and increasing CETC red line ( $p=0.038$, hazard ratio 1.99).

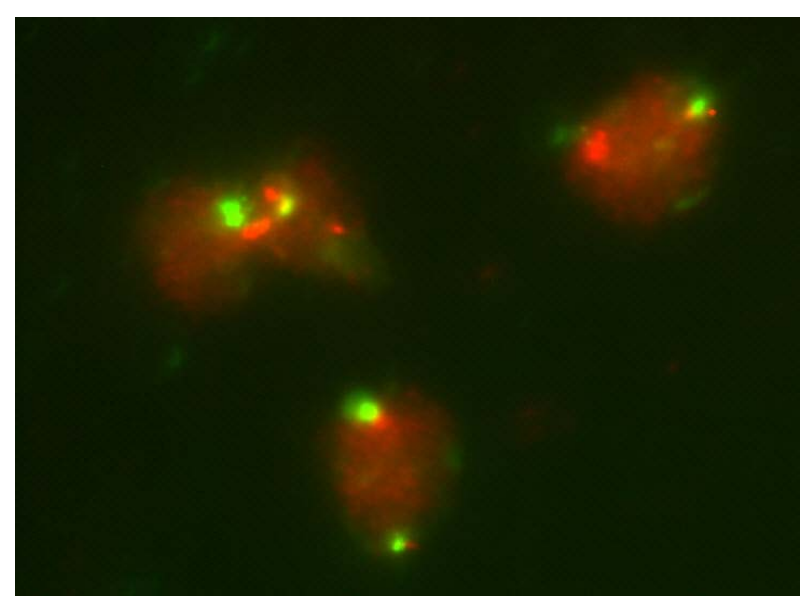

(a)

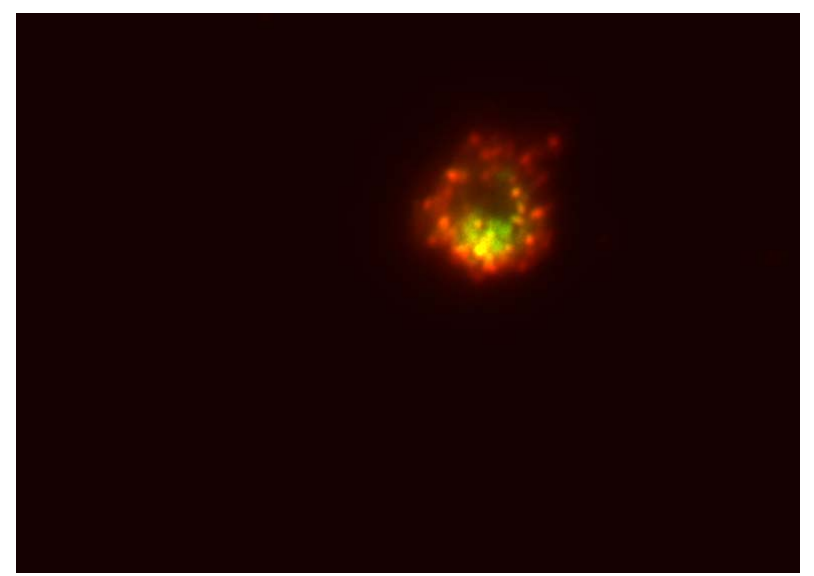

(b)

Figure 5. (a) 4 normal blood cells with two control signals and two EGFR gene signals and (b) an EpCAM positive cell of the same patient with amplified EGFR gene signals.

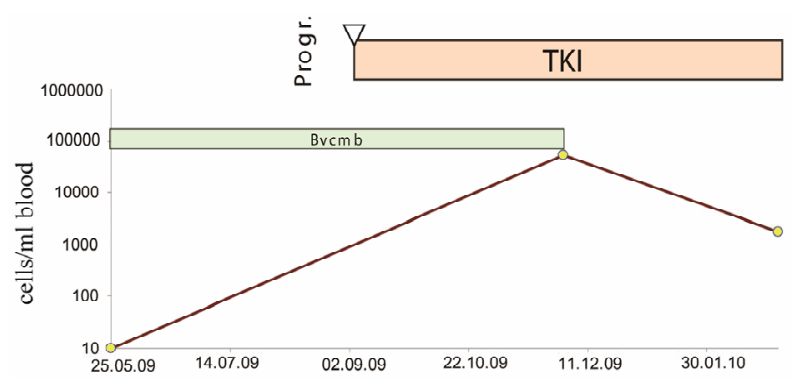

Figure 6. Patient 31 showing a steep increase in CETC in spite of anti-VEGF treatment with progress of his disease. This patient, however, showed a decrease in CETC upon receiving subsequently a tyrosine kinase inhibitor and is still in remission.

showed stable disease during the observation time.

\section{DISCUSSION}

Due to different efficacy in detection of circulating tumor cells the significance of the presence of epithelial cells circulating in the peripheral blood in cancer patients is still a matter of debate. Methods using enrichment procedures [25] may suffer from loss of relevant cell populations and nucleic acid based methods [18] do not allow for direct correlation to individual cells. An approach omitting all enrichment procedures using detection of positive cells by automated image analysis allows to detect all cells even with very low EpCAM espression and at the same time subsequent FISH analysis of these cells. Since it is not known how long such circulating tumor cells survive or to what extent they are able to form metastases it may not be the simple number of CETC but rather their behavior (increase or decrease) during the course of disease that may predict the patients' outcome. In breast cancer, patients at risk of relapse could be distinguished from patients remaining relapse free due to the response of the CETC to therapy [26].

It had been shown already in previous analyses in lung [14] and breast cancer patients [15] that increasing cell numbers after surgery are correlated with a higher risk of relapse, that patients with a good initial response to neoadjuvant treatment have improved relapse free survival [27], as well as that a stable number of CETCs can be detected without disease recurrence even after several years [8].

The present approach was designed to extend these previous results to patients receiving systemic therapy for advanced lung cancer.

In patients with advanced non small cell lung cancer circulating epithelial cells detected using our approach were shown to respond differently to chemotherapy. There was a strong correlation between a lack of reduction of CETC in response to chemotherapy and tumor 
progression or the appearance of new metastases and progression free survival was significantly higher in patients who's CETC responded to the applied therapies. This indicates that monitoring of CETCs already during the application of systemic therapy predicts whether the tumor ultimately will respond adequately to this therapy. Unnecessary toxicity during therapy could therefore be avoided by discontinuing ineffective therapy.

Since some of the cells circulating in blood might be able to settle in distant organs and grow into new metastases, repeated analysis is clearly more advantageous than a single analysis. In the present results in lung cancer patients with advanced disease a more than twofold increase in CETC numbers during therapy was highly predictive for relapse. This approach was subsequently combined with FISH identification to characterise CETCs by both epithelial specific antibodies and FISH to detect chromosomal abnormalities of the EGFR gene.

An increased number of EGFR-gene copies in almost all CETCs from patients with the amplification confirmed the tumor affiliation of the majority of CETCs. In addition, we were able to show that in one patient CETCs carrying the amplification were resistant to conventional drugs as shown by the increase in CETCs in spite of therapy, accompanied by progression. In contrast, CETCs responded to TKI accompanied by a response of his disease. CETC analysis in our view has three main areas of application: 1) evaluation of therapy response; 2) early detection of recurrence saving a considerable amount of time and 3) molecular analysis of circulating tumor cells. This allows adjusting therapy according to the molecular characteristics of the tumor and may, in the future, contribute to prevent ineffective treatments.

In addition, molecular analysis of circulating tumor cells from the blood of patients with lung [28] and other cancers offers the possibility of monitoring changes in epithelial tumor genotypes during the course of treatment.

Circulating tumor cells may be derived from multiple disease sites with different responses to therapy associated with an evolution in tumor genotype that may not be assessed by a single tissue biopsy performed at the time of presentation [29].

The method presented here permits easy, rapid, reliable and reproducible repeated quantitation of CETC in peripheral blood as well as identification of the genetic endowment of these cells. Such an approach can, in the future also be used to determine other gene amplifications and to perform gene expression analysis on isolated cells.

This could become a valuable and important tool for real time monitoring of therapy in vivo in addition to the estabished response criteria [30] and cancer genotype identification.

\section{REFERENCES}

[1] Jemal, A., Thun, M.J., Ries, L.A., Howe, H.L., Weir, H.K., Center, M.M., Ward, E., Wu, X.C., Eheman, C., Anderson, R., Ajani, U.A., Kohler, B. and Edwards, B.K. (2008) Annual report to the nation on the status of cancer, 1975-2005, featuring trends in lung cancer, tobacco use, and tobacco control. Journal of the National Cancer Initute, 100, 1672-1694. doi:10.1093/jnci/djn389

[2] Jemal, A., Murray, T., Sammuels, A., Ghafoor, A., Ward, E. and Thun, M.J. (2003) Cancer statistics. A Cancer Journal for Clinicians, 53, 5-26.

[3] Chen, Y.C., Hsu, H.S., Chen, Y.W., Tsai, T.H., How, C.K., Wang, C.Y., Hung, S.C., Chang, Y.L., Tsai, M.L., Lee, Y.Y., Ku, H.H. and Chiou, S.H. (2008) Oct 4 expression maintained cancer stem like properties in lung cancererived CD133-positive cells. Plosone, 3, e2637. doi:10.1371/journal.pone.0002637

[4] Borczuk, A.C., Gorenstein, L., Walter, K.L., Assaad, A.A. and Wang, L. (2003) Non-smal-cell lung cancer molecular signatures recapitulate lung developmental pathways. American Journal of Pathology, 163, 1949-1960. doi:10.1016/S0002-9440(10)63553-5

[5] Ashworth, T.R. (1969) A case of cancer in which similar cells similar to those in the tumour were seen in the blood after death. Australian Medical Journal, 14, 146-149.

[6] Liotta, L.A., KLeinerman, J. and Saidel, G.M. (1974) Quantitative relationship of intravascular tumor cells, tumor vessels and pulmonary metastases following tumor implantation. Cancer Research, 34, 997-1004.

[7] Meng, S., Tripathy, D., Frenkel, E.P., Shete, S., Naftalis, E.Z., Huth, J.F., Beitsch, P.D., Leitch, M., Hoover, S., Euhus, D., Haley, B., Morrison, L., Fleming, T.P., Herlyn, D., Terstappen, L.W., Fehm, T., Tucker, T.F., Lane, N., Wang, J. and Uhr, J.W. (2004) Circulating tumor cells in patients with breast cancer dormancy. Clinical Cancer Research, 10, 8152-8162.

doi:10.1158/1078-0432.CCR-04-1110

[8] Pachmann, K. (2005) Long time recirculating tumor cells in breast cancer patients. Clinical Cancer Research, 11, 5657-5658. doi:10.1158/1078-0432.CCR-05-0191

[9] Pachmann, K., Clement, J.H., Schneider, C.P., Willen, B., Camara, O., Pachmann, U. and Höffken, K. (2005) Standardized quantification of circulating peripheral tumor cells from lung and breast cancer. Clinical Chemistry and Laboratory Medicine, 43, 617-627. doi:10.1515/CCLM.2005.107

[10] Pachmann, K., Camara, O., Kavallaris, A., Schneider, U., Schünemann, S. and Höffken, K. (2005) Quantification of the response of circulating epithelial cells to neoadjuvant treatment for breast cancer: A new tool for therapy monitoring. Breast Cancer Research, 7, 975-979. doi:10.1186/bcr1328

[11] Solomayer, E.F., Diel, I.J., Salanti, G., Hahn, M., Gollan, C., Schütz, F. and Bastert, G. (2001) Time independence of the prognostic impact of tumour cell detection in the $\mathrm{BM}$ of primary breast cancer patients. Clinical Cancer Research, 7, 4102-4108. 
[12] Mansi, J.L., Gogas, H., Bliss, J.M., Gazet, J.C., Berger, U. and Coombes, R.C. (1999) Outcome of primary breast cancer patients with micrometastasis: A long term follow up study. Lancet, 354, 197-202. doi:10.1016/S0140-6736(98)10175-7

[13] Janni, W., Rack, B., Lindemann, K. and Harbeck, N. (2005) Detection of micrometastatic disease in bone marrow: Is it ready for prime time? Oncologist, 10, 480-492. doi:10.1634/theoncologist.10-7-480

[14] Rolle, A., Günzel, R., Pachmann, U., Willen, B., Höffken, K. and Pachmann, K. (2005) Increase in number of circulating disseminated epithelial cells after surgery for non-small lung cancer monitored by Maintrac is a predictor for relapse: A preliminary report. World Journal of Surgical Ooncology, 3, 18. doi:10.1186/1477-7819-3-18

[15] Camara, O., Kavallaris, A., Nöschel, H., Rengsberger, M., Jörke, C. and Pachmann, K. (2006) Seeding of epithelial cells into circulation during surgery for breast cancer: The fate of malignant and benign mobilized cells. World Journal of Surgical Ooncology, 4, 67. doi:10.1186/1477-7819-4-67

[16] Anni, W., Rack, B., Schindlbeck, C., Strobl, B., Rjosk, D., Braun, S., Sommer, H., Pantel, K., Gerber, B. and Friese, K. (2005) The persistence of isolated tumour cells in bone marrow from patients with breast carcinoma predicts an increase for recurrence. Cancer, 103, 884-891. doi:10.1002/cncr.20834

[17] Müller, V., Stahmann, N., Riethdorf, S., Rau, T., Zabel, T., Goetz, A., Jänicke, F. and Pantel, K. (2005) Circulating tumor cells in breast cancer: Correlation to bone marrow micrometastases, heterogeneous response to systemic therapy and low proliferative activity. Clinical Cancer Research, 11, 3678-3685. doi:10.1158/1078-0432.CCR-04-2469

[18] Vlems, F.A., Ladanyi, A., Gertler, R., Rosenberg, R., Diepstra, J.H., Röder, C., Nekarda, H., Molnar, B., Tulassay, Z., van Muijen, G.N. and Vogel, I. (2003) Reliability of quantitative reverse-transcriptase-PCR-based detection of tumour cells in the blood between different laboratories using a standardised protocol. European Journal of Cancer, 39, 388-396. doi:10.1016/S0959-8049(02)00631-7

[19] Baran, J., Pituch-Noworolska, A., Krzeszowiak, A., Wieckiewicz, J., Stachura, J., Popiela, T., Szczepanik, A. and Zembala, M. (1998) Detection of cancer cells in the blood by FACS sorting of CD 45-cells. International Journal of Molecular Medicine, 1, 573-578.

[20] Ntouroupi, T.G., Ashraf, S.Q., McGregor, S.B., Turney, B.W., Seppo, A., Kim, Y., Wang, X., Kilpatrick, M.W., Tsipouras, P., Tafas, T. and Bodmer, W.F. (2008) Detection of circulating tumour cells in peripheral blood with an automated scanning fluorescence microscope. British Journal of Cancer, 99, 789. doi:10.1038/sj.bjc.6604545

[21] Hirsch, F.R., Varella-Garcia, M., Bunn Jr, P.A., Di Maria, M.V., Veve, R., Bremmes, R.M., Barón, A.E., Zeng, C. and Franklin, W.A. (2003) Epidermal growth factor receptor in non-small-cell lung carcinoma: Correlation between gene copy number and protein expression and impact on prognosis. Journal of Clinical Oncology, 21, 3798-3807. doi:10.1200/JCO.2003.11.069
[22] Shepherd, F.A., Rodrigues, Pereira, J., Ciuleanu, T., Tan, E.H., Hirsh, V., Thongprasert, S., Campos D., Maoleekoonpiroj, S., Smylie, M., Martins, R., van Kooten, M., Dediu, M., Findlay, B., Tu D., Johnston, D., Bezjak A., Clark, G., Santabárbara, P., Seymour, L. and National Cancer Institute of Canada Clinical Trials Group (2005) Erlotinib in previously treated non-small-cell lung cancer. New England Journal of Medicine, 353, 123-132. doi:10.1056/NEJMoa050753

[23] Morinaga, R., Okamoto, I., Fujita, Y., Arao, T., Sekijima, M., Nishio, K., Ito, H., Fukuoka, M., Kadota, J. and Nakagawa, K. (2008) Association of epidermal growth factor receptor (EGFR) gene mutations with EGFR amplifycations in advanced non-small cell lung cancer. Cancer Science, 99, 2455-2460. doi:10.1111/j.1349-7006.2008.00962.x

[24] Pachmann, K., Camara O., Kohlhase, A., Rabenstein, C., Kroll, T., Runnebaum, I.B. and Hoeffken, K. (2010) Assessing the efficacy of targeted therapy using circulating epithelial tumor cells (CETC): The example of SERM therapy monitoring as a unique tool to individualise therapy. Journal of Cancer Research and Clinical Oncology, 137, 821-828. doi:10.1007/s00432-010-0942-4

[25] Lin, H., Balic, M., Zheng, S., Datar, R. and Cote, R.J. (2011) Disseminated and circulating tumor cells: Role in effective cancer management. Critical Reviews in Oncology/Hematology, 77, 1-11. doi:10.1016/j.critrevonc.2010.04.008

[26] Pachmann, K., Oumar, C., Kavallaris, A., Sabine, K., Malarski, N., Gajda, M., Kroll, T., Jörke, C., Hammer, U., Altendorf-Hofmann, A., Rabenstein, C., Pachmann, U., Runnebaum, I. and Höffken, A. (2008) Monitoring the response of circulating epithelial tumor cells to adjuvant chemotherapy in breast cancer allows detection of patients at risk of early relapse. Journal of Clinical Oncology, 26, 1208-1215. doi:10.1200/JCO.2007.13.6523

[27] Camara, O., Rengsberger, M., Egbe, A., Koch, A., Gajda, M., Hammer, U., Rabenstein, C., Untch, M. and Pachmann, K. (2007) The relevance of circulating epithelial tumor cells (CETC) for therapy monitoring during neoadjuvant (primary systemic) chemotherapy in breast cancer. Annals of Oncology, 18, 1484-1492. doi:10.1093/annonc/mdm206

[28] Maheswaran, S., Sequist, L.V., Nagrath, S., Ulkus, L., Brannigan, B., Collura, C.V., Inserra, E., Diederichs, S., Iafrate, A.J., Bell, D.W., Digumarthy, S., Muzikansky, A., Irimia, D., Settleman, J., Tompkins R.G., Lynch, T.J., Toner, M. and Haber, D.A. (2008) Detection of mutations in EGFR in circulating lung-cancer cells. New England Journal of Medicine, 359, 366-377. doi:10.1056/NEJMoa0800668

[29] Sequist, L.V., Martins, R.G., Spigel, D., Grunberg, S.M., Spira, A., Jänne, P.A., Joshi, V.A., McCollum, D., Evans, T.L., Muzikansky, A., Kuhlmann, G.L., Han, M., Goldberg, J.S., Settleman, J., Iafrate, A.J., Engelman J.A., Haber, D.A., Johnson, B.E. and Lynch, T.J. (2008) Firstline gefitinib in advanced nonsmall-cell lung cancer patients harboring somatic EGFR mutations. Journal of Clinical Oncology, 26, 2442-2449. doi:10.1200/JCO.2007.14.8494 
[30] Therasse, P., Arbuck, S.G., Eisenhauer, E.A., Wanders, J., Kaplan, R.S., Rubinstein, L., Verweij, J., Van Glabbeke, M., van Oosterom, A.T., Christian, M.C. and Gwyther, S.G. (2000) New guidelines to evaluate the response to treatment in solid tumors. European Organization for Re- search and Treatment of Cancer, National Cancer Institute of the United States, National Cancer Institute of Canada. Journal of National Cancer Institute, 92, 205-216. doi:10.1093/jnci/92.3.205 